\title{
Exploitation of Sea Resources and the Territorial Application of the Law of the Sea
}

\author{
EWA KURLANDA (Author and Corresponding author) \\ Address: 5 Russell Court, Strasburg Road, London, SW11 5HZ, UK \\ Tel: 44-778-863-0735 E-mail: ewa_kurlanda@yahoo.com \\ London Metropolitan University \\ Calcutta House, Old Castle Street, London E1 7NT, UK
}

\begin{abstract}
States have come together throughout the past decades in an effort to legalise navigation and trade activity on the seas. The international community have taken account of the traditional behaviour of coastal states towards each other as well as past discussions on the subject. Recently there has been much discussion on the UNCLOS, and the efforts and effects of this major piece of legislation on member and non-member states. Increase in global population and the advancement of technology in fisheries as well as increasing pollution of the seas have resulted in grave depletion of marine resources. State subsidies to the fishing sector have trade and ecological consequences, especially for fisheries that are over-exploited. Growing interest in this biological problem has sparked the need to establish principles which would rationalise exploitation of live aquatic wealth.
\end{abstract}

Keywords: International Law of the Sea, UNCLOS, EU Common Fisheries Policy, Subsidies, Sea resources, Exploitation

\section{Introduction}

States have historically cooperated on a range of functional and regional issues relating to navigation, nautical trade, fisheries, all of which led to a host of self-standing laws and principles. With nautical activity growing in both the commercial as well as services sector at swift speed, there arose a need to set down a list of principles which would be respected by all nations in order to minimise conflict. Industrialised global growth made sea-deprived states develop the demand to utilise marine resources on par with maritime countries.

Increase in global population and the advancement of technology in fisheries as well as increasing pollution of the seas have resulted in depleted marine resources, some of which have reached a startlingly low level. State subsidies to the fishing sector have trade and ecological consequences, especially for fisheries that are over-exploited. Growing interest in this biological problem has sparked the need to establish principles which would rationalise exploitation of live aquatic wealth.

This thesis will look into the incorporation into domestic law of the international law of the sea and its effect on states; to what extent countries can exercise their autonomous power over their coastlines and territorial seas and to what degree does this sovereign control affect marine resources.

The first section of this paper will explain the delimitation of the sea and its legal and administrative effects on the countries concerned.

The next segment of the study focuses on the territorial application of the law of the sea by countries. The chapter will introduce a discussion on the United Nations Convention on the Law of the Sea along with a critical analysis of the efforts of this major piece of legislation on member and non-member states. In light of this chapter, the following one will elaborate on the issues pertaining to current statistics relating to fisheries and usage of sea resources. The chapter will also provide the reader with the regulatory responses to excessive fishing and exploitation of sea resources.

Finally, the dissertation will go on to examine the reforms and efforts already undertaken and those planned to be introduced by the international community and the European Union to strengthen the weakened fisheries sector and to prevent any further overuse and misuse of marine wealth.

The final chapter will provide the reader with some concluding insight into the discussed topic.

\section{International Law of the Sea}

\subsection{Sources}

International law of the sea is the application of regulations and norms relating to oceanic regions and nautical activity. Nautical activity has been connected with foreign trade since antiquity and has always had an international flavour, which in turn required the establishment of norms and principles which would regulate various aspects of marine 
commerce.(Note 1) A major source of international law of the sea is that of custom and general practice of seafaring countries, which has evolved throughout the ages and has become the basis of the codification and unification of this area of law since the early 1900s. (Note 2) (Note 3) (Note 4)

\subsection{Delimitation}

Oceanic regions are one physical unit, but from the legal point of view they are divided into several zones which have different legal statuses. (Note 5)

The sovereignty of coastal states stretching out to a certain point of the sea is explained by security reasons and protection of state borders as well as the access of nationals of the country to marine life and mineral resources in the shallow oceanic regions, such as crude oil and natural gas. (Note 6)

State sovereignty is weakened seaward: first are internal waters, which include the waters of ports and bays. State sovereignty is unlimited in this part of the sea and foreign vessels cannot pass through it. The length of the internal waters cannot exceed 12 nautical miles from a demarcated baseline. (Note 7)

Beyond the coastal waters lays the Territorial Sea, which may be no wider than 24 nautical miles from the baseline (Note 8). This is a stretch of waters from the outer border of the outmost point of the coastal waters of the state and it also makes up part of state territory, but it is limited by the regime of innocent passage, assigned to all countries. The regime of innocent passage extends 12 nautical miles across. (Note 9)

Some countries delimitate a band of waters beyond their territorial waters called the Contiguous Zone. The Contiguous Zone does not form part of the country's borders, but the country can affirm rights, for example with regard to taxation, sanitation and immigration checks. If the country asserts the exclusive right to fish here, the band of waters will be called the exclusive fishery zone. Another form of self-imposed powers of a state beyond its demarcated borders is the right to the continental shelf, which consists of the continental slope and continental rise. The state has the right to use and exploit natural sea resources of the continental shelf as well as to conduct marine scientific research.

In recent years states have begun marking economic zones in their surrounding waters following debates over marine resources, particularly crude oil. In these zones the country can use and exploit any form of marine life and resources found in the zone waters, seabed and subsoil, thereby creating an area which combines the rights of the exclusive fishery zone and those of the continental shelf, called the exclusive economic zone (EEZ), which can extend up to 200 nautical miles from the baseline. (Note 10)

Outside these waters are the high seas, which are not under the sovereign laws of any country and from which all countries can make use of on an equal basis. The past decades have made steps towards establishing a separate legal status for the deep sea-bed outside the jurisdiction of any country in order to preserve it as common heritage of mankind. (Note 11)

In the following chapter we will see how this division is put into practice.

\section{The Convention}

\subsection{The Geneva Convention 1956}

In the $20^{\text {th }}$ century there arose the need to set down a set of rules which would provide guidance as well as legal enforcement regarding navigation and trade, in particular amongst arbitrary claims of various countries to extend their sovereignty beyond the traditional ones. For example, in 1945 U.S. President Truman claimed that the United States had exclusive rights to explore and exploit any natural resources found on the continental shelves extending from the country's coasts and based his claim on what was 'reasonable and just' (Note 13) (Note 14). Many countries followed his example; several South American countries asserted their rights on areas extending 200 nautical miles for fishing purposes in the Declaration of Santiago on the Maritime Zone of 1952, in which Chile, Ecuador and Peru proclaimed their sole jurisdiction and sovereignty over the area adjacent to and extending 200 miles from their coasts, including the sea floor and subsoil of that area. At the time, this move was largely seen as a response by states deprived of gradually descending continental shelves to compensate for their natural disadvantages. (Note 15) In post-war years, Australia made claims regarding the country's exclusive right to use the resources of the continental shelf in light of their lucrative pearling industry which faced fierce competition from long-range Japanese fleets. (Note 16) Amongst the plethora of such assertions the international community assembled in 1956 in Geneva, Switzerland, to legislate on the law of the sea.

\subsection{UNCLOS - Enactment}

The codification of customary marine law took place in 1958 under the auspice of the United Nations. Its end product was a series of four Conventions: on the Territorial Sea and Contiguous Zone, on the High Seas, on the Continental Shelf, and on Fishing and Conservation of Living Resources of the High Seas. (Note 17) 
Following the II Convention on the Law of the Sea in 1960, the group reunited seven years later in New York under the special guidance of Shirley Amerasinghe and Arvid Pardo(Note 18).

The Conference was finalised on 19 December 1982 by the establishment of the United Nations Convention on the Law of the Sea (UNCLOS), in force since November 1994. (Note 19). At the time of writing 160 states and the European Union are party to the Convention. (Note 20)

\subsection{UNCLOS - Analysis}

The Convention was enacted in a spirit of general optimism and the effects were far-reaching.

The Convention upheld the special status of the High Seas and allowed equal access to all nations with an open catalogue of the freedoms of the High Seas. (Note 21)

An important provision was the inclusion of the principle of Surplus Allowable Catch, by which the coastal State was obliged to give other States access to excess fisheries in the exclusive economic zone(Note 22).

Importantly, the Convention gave landlocked and geographically disadvantaged states access to and from the sea without the taxation of traffic through transit states, as well as the right to utilise the living resources of their neighbouring zones. (Note 23)

One of the major assets of the UNCLOS is a regime for controlling mineral resource exploitation in deep seabed areas beyond national jurisdiction as res communis, following the common heritage of mankind principle suggested by Malta's Arvid Pardo(Note 24). The special status of this area is supervised by an International Seabed Authority, which has sole authority to give permission to undertake marine research, scientific exploration, any exploitation of seabed minerals and resources whatsoever (Note 25).

However, it was the latter provision, along with most of Part XI of the Convention, which sparked disagreement from some states, the United States in particular, as a result of which the country did not become party to UNCLOS although it officially expressed agreement with the remaining clauses of the Treaty as customary international law (Note 26).

In recent years there has been a strong tendency - especially amongst highly developed countries - to revise the principles. One of the burning issues is the extension of state sovereignty beyond the established limits.

In May 2009 Argentina officially requested an extension of its sea rights to almost 350 nautical miles from the hitherto allowed 200 miles, with the exclusion of the waters surrounding the Falkland Islands, which are disputed with the United Kingdom. If the United Nations Convention on the Law of the Sea will assent to this expansion Argentina's overall surface will nearly double. India followed suit, requesting economic sovereignty over natural resources within 2.5 million sq $\mathrm{km}$ of ocean. (Note 27) (Note 28)

In this vein, the next chapter will look into the consequences of these claims and the expanding powers of nations over the sea in view of resources and environmental protection of stocks.

\section{Overhaul and Regulatory Responses}

\subsection{The Brink of Reason}

As noted above, the area outside the EEZ belongs to the High Seas (Note 29). Fishery in this area is subject to limitations and cannot be exploited as in territorial zones. (Note 30)

The absoluteness of the rights to this area, prior to the enactment of the UNCLOS, was qualified by the provision that the coastal state shall transfer rights to the sea beyond 200 nautical miles from the coast a proportion of the revenue obtained from the exploitation of the living and non-living resources of the "national open space" to the international institutions. (Note 31)

However, various fish species, for example tuna, are so-called 'straddling stocks', which means they are a migratory species that swim between the territorial and open sea boundaries, and thus are subject to the laws pertaining to the coastal state when present in its waters(Note 32). There is often severe competition between states for these stocks. What is tragic is that there are no incentives for countries to endeavour protection of these resources; often there are even disincentives for environmental protection, as we will see below in section 3.1.1. (Note 33) No doubt the Pardo Draft was intended to stem the tide of expanding national claims by conceding an outer limit designed to include the most extreme claims made until now, however, time has shown that the 200 -mile limit is not untouchable. For various reasons, for example because a particular current rich in living resources flows at a distance 300 or 500 miles from the coast, states may proceed from a once established minimum limit of 200 miles to further-reaching claims. (Note 34)

Meanwhile the depletion of marine life speaks for itself. It includes the near-extinct numbers of various species of whale, such as humpback and blue, primary responsibility of which take Japan and the former Soviet Union(Note 35) 
states which fish just outside their territorial areas, and once they have exhausted those supplies they move on to the next, intensive exploitation of tuna and shrimp by U.S. fleets outside the Latin American coasts(Note 36), the gradual destruction of Atlantic salmon breeding grounds by the practice of Danish fisherman in catching the salmon just before they spawn(Note 37), overfishing in the Mediterranean and other major bodies of water(Note 38).

With 7 billion Euros of total revenue from the fisheries sector in the EU alone and with the absence of regulations which would impose penalties for noncompliance there can hardly be any state encouragement to minimise hauls. (Note 39)

\subsubsection{Subsidies}

Since the 1970s, fisheries subsidies were introduced to boost fish production by supporting investment in larger and more efficient fleets and encouraging employment in this highly lucrative food sector. There is a broad array of validations for subsidies to the fisheries sector, for example the protection of developing industries, national food security, ensuring optimum wealth utilisation and social arguments such as the preservation of livelihoods and poverty reduction. (Note 40) In the 1980s and 1990s many countries were focussed on expanding national fleets and the fishing sector therefore provided financial assistance for the development of new technologies and modernisation of fleets in response to the high demand (Note 41) for seafood and fish delicacies such as caviar.

It seems, conversely, that not much thought was given to accommodate fleet sizes to available stocks. (Note 42) The result is that the net contribution of fisheries to the global economy is substantially negative, with total operating costs higher than gross revenue - and with part of the deficit funded by the subsidies themselves. The World Bank estimated the cumulative global loss of potential economic benefits from fisheries at USD 2 trillion over the last three decades, as a result of the overexploitation of stocks and consequent loss in productivity (Note 43).

In British waters alone, scientists estimate fish stocks have declined by a staggering $94 \%$ in the past century alone and commercial fishing has profoundly changed seabed ecosystems, leading to a collapse in numbers of many species. (Note 44)

At the speed at which man is going, estimates say seafood will be a rarity by 2050. (Note 45)

The natural question arises - what has been done - or what is planned to be done - to curtail the destructive rate at which the fisheries sector is going?

\subsubsection{An UNCLOS response}

The UNCLOS does not ignore the issue - Articles 61 - 71 relate to the use of natural resources as one of the sovereign rights a coastal state enjoys(Note 46) Article 61 sets out a series of principles which explain the danger of overfishing and encourages the country to make sure that nationals fish prudently within their exclusive economic zones (EEZ), always bearing in mind the extent of their fishing, the type of fish involved along with its natural habitat and possible influence on other stocks which could be potentially affected. Data on species living within the zone should be systematically collected and published for the benefit of the coastal state nationals along with nationals of any other state which has access to the fisheries in question. (Note 47)

Article 62 of the UNCLOS allows the country to valuate its own living resources and to assess its fishing possibilities in light of the UN-promoted principle of 'optimum utilisation' of fisheries. (Note 48)

However, the Convention does not specify who will appraise the resources and without independent third party valuation there is great risk for countries to lack the incentive to follow the guidelines aimed at protecting marine wealth. A further problem is that the EEZ can extend 200 nautical miles, which in effect means that most species of fish - studies show up to $90 \%$ (Note 49) - find themselves in this area therefore they are not protected by the freedoms of the High Seas and are subject to the total autonomy of the coastal state.

UNCLOS provides that all states will maintain their use of the traditional freedoms of fishing in the high seas, but this right is qualified by the need to conserve living resources. (Note 50) States which allow fishing in the high seas are expected to cooperate to conserve and manage living resources and to establish regional institutions for this purpose. (Note 51) The organisations which are to oversee this activity are called 'regional fisheries management organizations' (RFMOs). (Note 52)

\subsection{International Law}

State interest in the fisheries sector has resulted in convergence under the backing of several treaties and international organizations, such as the World Food and Agriculture Organisation of the United Nations (FAO), species-specific and regional fisheries management organisations, and environmental treaties such as the Convention on the International Trade in Endangered Species of Wild Flora and Fauna (CITES), the International Tribunal of the Law of the Sea. (Note 53) 
Endeavours to engage in the administration of the high seas resulted in a 'Fish Stocks Agreement' in 1995. (Note 54) The Agreement relates in particular to straddling stocks and provides that parties which fail to become members of an existing regional regime and refuse to apply conservation and management measures can be denied access to the fishery. (Note 55)

A first glance at the text raises questions. Article 3(1) gives the discretion to states to manage their stocks subject to the different legal regimes that apply and goes on further in subsection 3 to give due consideration (...) of developing States. (Note 56)

Other provisions give leave to states to 'adopt measures' to 'ensure that such measures are based on the best scientific evidence available' (Note 57) However, their vagueness suggests they will not be strictly enforceable.

\subsubsection{World Food and Agriculture Organisation of the United Nations}

Although also under the ambit of the United Nations, the FAO, made up of several governing bodies, including bodies such as the Committee on Fisheries in which members may apply to participate (Note 58), has introduced an alternative approach, albeit still within the soft law regime, mainly, it focuses on the collection, compilation, analysis and publication of fisheries data and provides a backdrop for the revisiting and amending of agreements and technical guidelines. (Note 59)

Probably one of the most important spheres of interest of the FAO is the reaching of understandings between the organisation and its subsidiaries and regional institutions which are best informed on the matter. (Note 60) Because of the state subsidiaries, as well as any other rewards or incentives, employment in this sector has expanded and recent years have shown that the problem includes social factors in addition to the economic ones. (Note 50) (Note 61)

In addition, maximum catch allowance quotas without regulation of vessel numbers has resulted in fish discards where taking the catch back to land would result in penalties, fisherman throw their catch overboard. Conservation groups say that in 2007 fishermen landed 24,000 tonnes of cod in the North Sea but threw another 23,000 tonnes overboard to avoid breaking quota rules. (Note 62) EU Commissioner for Fisheries and Marine Affairs, Joe Borg, has called for sweeping reforms to the quota-based system, noting that "we have to get out of the current situation, where too many boats are chasing too few fish." (Note 63)

This, in conjunction with the problem of IUU fishing (Note 64), introduces the challenge of introducing local groups into the problem and dealing with social implications of regulatory responses. In 1995 the FAO conference adopted the Code of Conduct for Responsible Fisheries ('Code of Conduct'), which implemented the need to engage with technical, socio-economic and environmental factors relating to sustainable fishing. (Note 65) Pressing on the duty of states to cooperate through regional institutions, the Code of Conduct is also directed at fishing entities, NGOs, and fishermen themselves. (Note 66)

The organisation has also come to the far-reaching conclusion that the question of overhaul must be dealt with by more drastic measures - excessive fisheries must be eliminated and surplus vessels eradicated, (Note 67) whereas illegal or unreported fishing can no longer be tolerated.

More importantly, the FAO addresses the delicate and yet key issue of state incentivisation and calls upon states to 'reduce and progressively eliminate all factors, including subsidies and economic incentives ... which contribute, directly or indirectly, to the build-up of excessive fishing capacity' (Note 68) by calling on states to 'avoid conferring economic support, including subsidies, to companies, vessels or persons that are involved in IUU fishing' (Note 69) In its primary function of collecting and diffusing data, the FAO will gather information on the combating of subsidies and addressing these issues for the wider benefit. (Note 70)

\subsubsection{Other organisations}

Outside of the WTO, other organizations such as UN Environment Program, the WWF (Note 71), International Centre for Trade and Sustainable Development have become involved by organising meetings, conferences and public awareness days. Although obviously lacking strong legal enforcement, these endeavours cannot be undervalued as they expand general alertness to the problem and encourage government stakeholders (including environment, trade, and fisheries agencies officials), intergovernmental organizations, RFMOs, NGOs, and academic institutions to participate. (Note 72)

\subsection{The European Union}

As the European Union is observed as one economic market, all Member States have one common EEZ and equal access to Member State waters, as set down in 1970. (Note 73) This today has evolved to common fishery problems and - stemming therefrom - common fisheries policies. 
Europe's fishing fleet is the world's third largest. (Note 74) Statistics show that The EU fleet landed 4.44 million tonnes of fish in 2006, worth 6.7 billion Euros. The latest EU data show that fishing and processing provided work for 229,702 people in the bloc in 2004. (Note 75)

The EU began taking a keen interest in the international law of the sea in the late 1970s, when trend had it to extend coastal state sovereignty from the 12 - to the 200-mile limit. In the 1980s the Community introduced the Common Fisheries Policy (CEP), an organisation in charge of ensuring the EU was in defence of its rights with regard to marine exploitation (Note 76). It was not until the past decade that the EU began seriously considering the pressing issues in question. In 2002 the CEP was reformed in view of sustainability of fisheries and the effect of any new laws on the socio-economic behaviour of these markets and the standard of living of those nationals who depend on fishing as their only livelihood, whereas six years later the CEP underwent a further alteration with the aim of achieving a substantial refurbishment of the strategy with the deadline of 2012. (Note 77)

\subsubsection{Community Fisheries Control Agency and Common Fisheries Policy}

In 2005 the EU established the Community Fisheries Control Agency which audits the compliance with set standards regarding the long-term survival of fish stocks and coordinates enforcement of rules to prevent over-fishing and to protect other forms of marine life. (Note 78) (Note 79)

With time the resolution of the problem of subsidies has been recognised within the EU and various pieces of legislation have been introduced in order to tackle the topic of concern. One was Council Regulation (EC) No 1263/1999 of 21 June 1999 on the Financial Instrument for Fisheries Guidance (FIFG) (Note 80). One of the aims of this enactment, being the financial component of the CFP - which ran between 2000 and 2006 with $€ 4.119$ billion was to "contribute to achieving a balance between fisheries resources and their exploitation".(Note 81)

However, the WTO has criticised the EU's attempt to solve the problem of subsidies by putting forward a catch-all prohibition which would prohibit subsidies where the benefits 'are conferred on any fishing vessel or fishing activity affecting fish stocks that are in an unequivocally overfished condition' (Note 82), as the word 'unequivocally' remained undefined in the draft and therefore allowed for discrepancy and flexible interpretation. (Note 83)

Currently the European Fisheries Fund succeeded the FIFG and has been in charge of 'the support of sustainable exploitation of fisheries resources and ensuring a stable balance between these resources and the capacity of Community fishing fleet.' (Note 84) Its total budget is of around 3.8 billion euros and running time from 2007 to 2013. (Note 85)

The CEP has set up several measures for environmental sustainability of natural marine resources, such as total allowable catches, limitation of fishing effort, technical measures (as regards fishing gear and vessel size), fleet management, strategies for the avoidance of bycatches and fish discards. (Note 81) Annexes IV and V(Note 82) prepare Member State for unscheduled audits on documents relating to financial plans, business developments and other information which must be kept on hand and adhered to to fully implement the Regulation. (Note 83) Any irregularities between the implemented rules and the Regulation must be reported to the Commission and data will be stored on a specially designed database (Note 84). The deadline for suggestions to interim provisions must be submitted by the Member State to the Commission no later than 30 June 2011. (Note 85)

Meanwhile the need for a revision of fishing quotas has taken effect in Brussels at the EU Fisheries Council in December 2009. Hauls for cod, sole, haddock and Norway lobster have been cut up to $20 \%$, whereas that of herring up to $70 \%$. Fishing for endangered porbeagle and spurdog sharks has been banned. (Note 86)

In addition, Denmark has proposed that CCTV cameras be introduced on fishing boats to ensure compliance with catch allowances and to hinder the wasteful practice of discards. (Note 87)

\subsection{Assessment}

Subsidising the fisheries sector is perhaps the most serious of points to engage in as it is directly responsible for the number of fleets which will commit the exploitation. However, the importance of this issue is directly proportional to the difficulty of addressing the matter as opinions on the subject differ from state to state and often divergences are too wide to bring together.

In April 2009 WTO Rules Group gathered in order to pose pressing questions for the Chair to address in the "Chair's text on fisheries subsidies" (Note 88). In that roadmap, the Chair, Ambassador Guillermo Valles Galmes of Uruguay, had said that "it is clear from the discussions that the participants' views still differ widely regarding which subsidies should be prohibited".(Note 89)

The U.S. proposed that all and any subsidies which contribute to overfishing and overcapacity should be eliminated; whereas countries of the Far East claimed only those subsidies which directly contribute to overfishing should be 
prohibited(Note 90). There were those countries, such as India, Malaysia and Indonesia claimed that subsidies should continue for developing countries. The same was put forward by El Salvador on behalf of small and vulnerable economies, while the "Friends of Fish" faction, which, among others, groups New Zealand, Argentina, Brazil and Australia stressed the need to indeed discontinue subsidisation in light of the WTO's latest dire reports on fish stocks. (Note 91) The EU proposed subsidies to developing countries be conditional to their fishing capacity not increasing to an extent that it presented an 'impediment to the sustainable exploitation of fishery resources worldwide' (Note 92)

It has been pointed out that the question of the states which offer 'flags of convenience' should be addressed. (Note 93) Even if measures developed within the regional fisheries management organisations are accurate enough for most states, some nationals will register their vessels with non-member states and reflag their fleet. It is most often these ships which undertake IUU fishing. (Note 94)

\section{Conclusion}

Throughout the past two decades there has been established a multitude of groups, assemblies and organisations which encourage implementation of compliance methods introduced by various legislation, starting from the UNCLOS.

The difficulty in these laws is that they remain in the domain of soft law, which allows states to enter into the arrangements at their will. They can also opt out whenever occasion deems it convenient. Unfortunately, this approach is not sufficient in light of the dwindling numbers of marine life. Attempts to deal with the problem vertically are well based, however, with the lack of regional support this has yet enjoyed mediocre results and direct support from international law is not as effective as it ought to be. The UN Division for Ocean Affairs and the Law of the Sea relates widely to the UNCLOS but does not identify specifications to the fisheries themselves. (Note 95) The FAO has perhaps been more successful in this field, as it is crucial to stress the need for relevant and transparent scientific data regarding environmental protection of the resources as well as the importance of spreading public awareness. Nonetheless, strict enforcement of the laws are yet to be seen as annual resolutions and broad oversight can only complement, but not replace, compliance regulation, monitoring of regulation implementation and internal audits.

Economic and social arguments constitute a major setback to the discussions as many developing countries depend to a great extent on the fishery sector and limits on subsidies or entertaining suggestions on haul limits would cause much economic turmoil in these nations. Arguments are suggested for a more regional approach instead of a global one. Some developed countries, such as Norway and Scotland, also face cuts in view of the newest quotas cited above and limitations for days spent at sea(Note 96).

At any rate, it seems as though subsidy discussions have not yet made any substantial difference. There is a lack of cooperation between states and their differences of opinion are reflected in their non-compliance with standards. National and regional plans of action will only be effective once there is a unified approach towards enforcing and assessing strict conformity with the rules.

Study groups and assemblies specialising in collection of data should cooperate with non-governmental organisations; the WTO with FAO, regional institutions with national ones; international with state. There must be less of a 'member-focussed' approach and instead attempts should be made to unify assessment without the need to be party to any specific organisation which would exclude the voices - and indeed omit the non-obedience - of some nations.

In light of diminishing marine wealth and the very real consequences of overfishing it must be accepted and acknowledged that the rules of previous years of 'optimum utilisation' and 'without prejudice to developing countries, which rely on the fisheries sector' can no longer be prioritised as it is a worldwide issue with worldwide consequences. With the spreading of awareness and strict adherence to quotas, it will only be in the global interest to ensure the preservation of marine life and natural resources.

\section{References}

Agreement for the Implementation of the Provisions of the United Nations Convention on the Law of the Sea of 10 December 1982 relating to the Conservation and Management of Straddling Fish Stocks and Highly Migratory Fish Stocks. (2008). Last viewed 14 April 2010. [Online] Available: http://www.un.org/Depts/los/convention_agreements/convention_agreements.htm.

Argentina: Government to extend sea sovereignty. Abstract from La Nacion (Argentina), 07 June 2008.

Burke, W. (1994). The New International Law of Fisheries: UNCLOS 1982 and Beyond, p. 23.

Charter, D. (2009) Too many boats chasing down too few fish. Times Online, 16 April 2009. Last viewed 28 March 2010. [Online] Available: http://www.timesonline.co.uk/tol/travel/news/article6101802.ece. 
Churchill, R.R., Lowe, A.V. (1999). The law of the sea. Manchester University Press 1983, p xxix and 3rd edn, pp. 296-305.

De La Fayette, L. (2006). The Role of the United Nations in International Oceans Governance. In D. Freestone, R. Barnes, \& D. Ong. (2006). The Law of the Sea: Progress and Prospects, p. 63.

DeWalle, F.B., Nikolopoulou-Tamvakli, M., \& Heinen, W.J. (1993). Environmental condition of the Mediterranean Sea: European Community countries, Kluwer Academic Publishers, p. 8.

Dupuy, R.J., Vignes, D. (1991). A Handbook on the new law of the sea Volume 2. Hague Academy of International Law. Kluwer Academic Publishers, pp. 142 - 148.

EU agrees on 2010 fishing limits. BBC News. Reported 16 December 2009. [Online] Available: http://news.bbc.co.uk/1/hi/8415760.stm.

EU to overhaul fisheries policy. 17 September 2008. Last viewed 31 March 2010. [Online] Available: http://news.bbc.co.uk/1/hi/7621618.stm.

EU vows to tackle overfishing with policy overhaul. May 2010. Last viewed 08 May 2010. [Online] Available: http://www.euractiv.com/en/cap/eu-vows-to-tackle-overfishing-with-policy-overhaul-news-493796.

Europa: FIFG: Financial Instrument for Fisheries Guidance, Council Regulation (EC) No 1263/1999 of 21 June 1999 on the Financial Instrument for Fisheries Guidance, last viewed 24 April 2010. [Online] Available: http://europa.eu/legislation_summaries/maritime_affairs_and_fisheries/fisheries_sector_organisation_and_financing /160017_en.htm.

Europa: Gateway to the European Union, Maritime Affairs and Fisheries, last viewed 08 May 2010. [Online] Available: http://europa.eu/pol/fish/index_en.htm.

European Commission, Fisheries, About the Common Fisheries Policy, last viewed 09 May 2010. [Online] Available: http://ec.europa.eu/fisheries/cfp_en.htm.

FAO Code of Conduct. [Online] Available: http://www.fao.org/DOCREP/005/v9878e/v9878e00.htm\#BAC.

FAO webpage. [Online] Available: http://www.fao.org/.

Frank, V. (2007). The European Community and Marine Environmental Protection in the International Law of the Sea. In Implementing Global Obligations at the Regional Level. Martinus Nijhoff Publishers, The Netherlands.

Friedmann, W. (1971). Selden Redivivus - Towards a Partition of the Seas? The American Journal of International Law, Vol 65, No 4, pp. $757-770$.

Goralczyk, W. (1993). Divisions of the sea and its delimitation, Warsaw.

Goralczyk, W., Sawicki, S. (2006). International Law of the Sea. In International Public Law - an overview, Lexis Nexis Publishing, Warsaw, p. 200.

Grozio, U. (2007). Mare Liberum, Liguori Editore, Napoli.

Hardin, G. (1968). 'The Tragedy of the Commons' Science, 1243.

India finalising claims on continental shelf to extend economic sovereignty. Excerpt from the Hindustan Times, 08 March 2009.

Klein, N. (2005). Dispute Settlement in the UN Convention on the Law of the Sea. Cambridge Studies in International and Comparative Law, University Press Cambridge, p 323.

Koh, T.T. (1983). A Constitution for the Oceans. United Nations, The Law of the Sea: Official Text of the United Nations Convention on the law of the Sea with Annexes and Index, New York, p xxxv.

Lopuski, J. (1996). Sea Law, Bydgoszcz.

Lukaszuk, L. (1997). International Law of the Sea, Warsaw.

Malanczuk, P., Akehurst, M.B. (1997). Akehurst's Modern Introduction to International Law, Seventh Edition, Routledge, p. 173.

Matysik, S. (1967). Textbook on the Law of the Sea, Warsaw, p. 12. See also Mlynarczyk, J. (1997). Sea Law, Gdansk, p. 14.

Oceans and Law of the Sea, Division for Ocean Affairs and the Law of the Sea - Consolidated table of ratifications/accessions, as of 01 January 2010. Last viewed on 13 May 2010. [Online] Available: http://www.un.org/Depts/los/reference_files/status2010.pdf. 
Report of the meeting of fisheries managers and ministers of the WECAFC, Western Central Atlantic Fishery Commission, at $\mathrm{p} 33$.

Schram Stokke, O. (2001). (ed.) Governing High Seas Fisheries: The Interplay of Global and Regional Regimes, p. 303.

Scott, S.V. (1992). The inclusion of sedentary fisheries within the continental shelf doctrine. International and Comparative Law Quarterly.

Scully, M. (2002). Dominion: the power of man, the suffering of animals and the call to mercy, St Martin's Press

Statement of revenue and expenditure of the Community Fisheries Control Agency for the financial year 2009 Amending Budget No 2 (2010/26/EU).

Symonides, J. (1986). New Law of the Sea, Warsaw.

The Committee on Fisheries (COFI). [Online] Available: http://www.fao.org/fishery/about/cofi/en.

The progress of the common fisheries policy: Report. Volume 2.

The Sunken Billions: The economic justification for fisheries reform. Conference Edition. World Bank, 2008.

Update: fishing countries must respect Doha message, says WWF, 25 March 2010, last viewed 09 May 2010. [Online] Available: http://www.worldwildlife.org/who/media/press/2010/WWFPresitem15793.html.

Wilder, R.J. (1998). Listening to the sea: the politics of improving environmental protection. University of Pittsburgh Press, Pittsburgh, PA, p. 14.

WTO Rules Group discusses Chair's text on fisheries subsidies.

Published in SUNS \#6674. 3 April 2009. Third World Network. [Online] Available: http://www.twnside.org.sg/title2/wto.info/2009/twninfo20090410.htm.

WTO Disciplines on fisheries subsidies, Elements of the Chair's Draft. 29 January 2008. Workshop Report, Geneva, Switzerland.

WWF website dedicated to IUU fishing. Last viewed 09 May 2010. [Online] Available: http://iuufishing.org/.

Young, M.A. (2009). Fragmentation or interaction: the WTO fisheries subsidies, and international law. World Trade Review.

\section{Notes}

Note 1. Lukaszuk, L. (1997). International Law of the Sea, Warsaw.

Note 2. Lopuski, J. (1996). Sea Law, Bydgoszcz.

Note 3. Symonides, J. (1986). New Law of the Sea, Warsaw.

Note 4. Matysik, S. (1997). Textbook on the Law of the Sea, Warsaw, 12. See also Mlynarczyk, J. (1997). Sea Law, Gdansk, 14.

Note 5. Goralczyk, W \& Sawicki, S. (2006). 'International Law of the Sea', in International Public Law - an overview. Warsaw, Lexis Nexis Publishing, 200.

Note 6. Ibid

Note 7. Goralczyk, W. (1993). Divisions of the sea and its delimitation, Warsaw.

Note 8. Article 3 of the UNCLOS

Note 9. Articles 18 and 19 of the UNCLOS.

Note 10. Articles 55 and 56 of the UNCLOS

Note 11. Supra note 7

Note 12.Wilder, R J. (1998). Listening to the sea: the politics of improving environmental protection, University of Pittsburgh Press, Pittsburgh, PA, 14

Note 13.Grozio, U. (2007). Mare Liberum, Liguori Editore, Napoli.

Note 14.Scott, SV. (1992). 'The inclusion of sedentary fisheries within the continental shelf doctrine', in International and Comparative Law Quarterly.

Note 15.Friedmann, W. (1971). 'Selden Redivivus - Towards a Partition of the Seas?' The American Journal of International Law, Vol 65, No 4, 757 - 770 . 
Note 16. Ibid;

Note 17. Supra note 5

Note 18.Malanczuk, P \& Akehurst, M B. (1997). Akehurst's Modern Introduction to International Law, Seventh Edition, Routledge, 173.

Note 19. Ibid

Note 20. Oceans and Law of the Sea, Division for Ocean Affairs and the Law of the Sea - Consolidated table of ratifications/accessions, as of 01 January 2010. Last viewed on 13 May 2010, [Online] Available: http://www.un.org/Depts/los/reference_files/status2010.pdf

Note 21. Some of which include navigation, overflight, laying pipes and cables, the creation of artificial islands, the conducting of scientific research. See supra note 5.

Note 22. Young, M A. (2009) 'Fragmentation or interaction: the WTO fisheries subsidies, and international law', World Trade Review.

Note 23. Koh, T T. (1983). "A Constitution for the Oceans", in United Nations, The Law of the Sea: Official Text of the United Nations Convention on the law of the Sea with Annexes and Index, New York, xxxv

Note 24. Dupuy, R J \& Vignes, D. (1991). A Handbook on the new law of the sea (Volume 2), Hague Academy of International Law, Kluwer Academic Publishers, 142 - 148.

Note 25. Ibid, 635

Note 26. Klein, N. (2005). 'Dispute Settlement in the UN Convention on the Law of the Sea', Cambridge Studies in International and Comparative Law, University Press Cambridge, 323.

Note 27. 'Argentina: Government to extend sea sovereignty', abstract from La Nacion (Argentina), 07 June 2008

Note 28. 'India finalising claims on continental shelf to extend economic sovereignty', excerpt from the Hindustan Times, 08 March 2009

Note 29. UNCLOS, articles 116 - 120

Note 30. Supra note 5 at $\mathrm{p} 215$

Note31. Supra note 15

Note32. Hardin, G. (1968). 'The Tragedy of the Commons' Science 1243.

Note33. Supra note 22

Note34. Supra note 15

Note35. Scully, M. (2002). Dominion: the power of man, the suffering of animals and the call to mercy, St Martin's Press.

Note36. Western Central Atlantic Fishery Commission, Report of the meeting of fisheries managers and ministers of the WECAFC at $\mathrm{p} 33$

Note37. Churchill, R R \& Lowe, A V. (1983). The law of the sea, Manchester University Press, xxix and 3rd edn, (1999), 296-305.

Note38. DeWalle, F B \& Nikolopoulou-Tamvakli, M \& Heinen, W J. (1993). Environmental condition of the Mediterranean Sea: European Community countries, Kluwer Academic Publishers, 8.

Note39. Statement of revenue and expenditure of the Community Fisheries Control Agency for the financial year 2009 - Amending Budget No 2 (2010/26/EU)

'Note 40. The Sunken Billions: The economic justification for fisheries reform'. Conference Edition. World Bank, 2008

Note 41.Ibid

Note 42. 'EU vows to tackle overfishing with policy overhaul', May 2010, last viewed 08 May 2010, [Online] Available: http://www.euractiv.com/en/cap/eu-vows-to-tackle-overfishing-with-policy-overhaul-news-493796

Note 43.Ibid

Note 44.Ibid

Note 45. 'EU to overhaul fisheries policy', 17 September 2008, last viewed 31 March 2010, [Online] Available: http://news.bbc.co.uk/1/hi/7621618.stm 
Note 46. UNCLOS, article 61

Note 47.Ibid

Note 48.UNCLOS, article 62

Note 49.Burke, W. (1994). The New International Law of Fisheries: UNCLOS 1982 and Beyond, 23.

Note 50.UNCLOS, Art. 116-119. This was the basis of Chile's claim in the swordfish dispute

Note 51.Ibid, Art. 118.

Note 52.Supra note 37

Note 53.WWF website, [Online] Available:

http://www.worldwildlife.org/who/media/press/2010/WWFPresitem15793.html

Note 54 'Agreement for the Implementation of the Provisions of the UNCLOS of 10.12.82 relating to the Conservation and Management of Straddling Fish Stocks and Highly Migratory Fish Stocks', 04.12.08, last viewed 14.04.10, [Online] Available: http://www.un.org/Depts/los/convention_agreements/convention_agreements.html

Note 55. Fish Stocks Agreement, Articles 3 - 8

Note 56. Ibid

Note 57. Ibid, Part II, Article 5

Note 58. The Committee on Fisheries (COFI). [Online] Available: http://www.fao.org/fishery/about/cofi/en

Note 59. For example the biennial State of World Fisheries and Aquaculture, which depends heavily on inputs from domestic agencies: SOFIA (2006). See also supra note 22

Note 60. FAO webpage. [Online] Available: http://www.fao.org/

Note 61. Ibid

Note 62. Charter, D. (16 April 2009). 'Too many boats chasing down too few fish', Times Online, last viewed 28 March 2010, [Online] Available: http://www.timesonline.co.uk/tol/travel/news/article6101802.ece

Note 63. Ibid

Note 64. IUU fishing, see below at note referring to WWF website.

Note 65. FAO Code of Conduct, Art. 3.2(c). [Online] Available: http://www.fao.org/DOCREP/005/v9878e/v9878e00.htm\#BAC.

Note 66. FAO Code of Conduct, Art 6.12

Note 67. FAO Code of Conduct Arts. 7.1.8 and 7.6.3.

Note 68. IPOA-Capacity, para. 256.

Note 69. IPOA-IUU paragraphs 23 - 88

Note 70. Supra note 22

Note 71.See: 'Update: fishing countries must respect Doha message, says WWF', 25 March 2010, last viewed 09.05.2010, [Online] Available: http://www.worldwildlife.org/who/media/press/2010/WWFPresitem15793.html

Note 72.Supra note 22

Note 73. European Commission, Fisheries, About the Common Fisheries Policy, last viewed 09 May 2010, [Online] Available: http://ec.europa.eu/fisheries/cfp_en.htm

Note 74.Supra note 42

Note 75.These numbers are not from within the European waters themselves as the European Union has entered into 20 bilateral fishing agreements, primarily with developing countries in Africa, which allow EU vessels to fish within the EEZs of these countries. See Young, M \& Witbooi, E. (2008) 'Governing Global Fisheries: Commons, Community Law and Third-Country Coastal Waters', 17(3) Social and Legal Studies 369.

Note 76. Frank, V. (2007). 'The European Community and Marine Environmental Protection in the International Law of the Sea', Implementing Global Obligations at the Regional Level, Martinus Nijhoff Publishers, The Netherlands.

Note 77. Supra note 42 
Note 78.Europa: Gateway to the European Union, Maritime Affairs and Fisheries, last viewed 08 May 2010, [Online] Available: http://europa.eu/pol/fish/index_en.htm

Note 79. Ibid

Note 80.Ibid

Note 81.Europa: FIFG: Financial Instrument for Fisheries Guidance, Council Regulation (EC) No 1263/1999 of 21 June 1999 on the Financial Instrument for Fisheries Guidance, last viewed 24 April 2010, [Online] Available: http://europa.eu/legislation_summaries/maritime_affairs_and_fisheries/fisheries_sector_organisation_and_financing /160017_en.htm

Note 82.WTO Disciplines on fisheries subsidies, Elements of the Chair's Draft, Workshop Report, Geneva, Switzerland, 29 January 2008

Note 83.Ibid

Note 84.Supra note 81

Note 85.Ibid

Note 86.Supra note 73

Note 87. Annex IV and V of the Commission Regulation (EC) No 498/2007 of 26 March 2007 laying down detailed rules for the implementation of Council Regulation (EC) No 1198/2006 on the European Fisheries Fund

Note 88.Supra note 81

Note 89.Ibid

Note 90.Ibid

Note 91.'EU agrees on 2010 fishing limits', BBC News, reported 16 December 2009. [Online] Available: http://news.bbc.co.uk/1/hi/8415760.stm

Note 92.Ibid

Note 93. 'The progress of the common fisheries policy: Report', Volume 2

Note 94. 'WTO Rules Group discusses Chair's text on fisheries subsidies

Published in SUNS \#6674', 3 April 2009, Third World Network, [Online] Available: http://www.twnside.org.sg/title2/wto.info/2009/twninfo20090410.htm

Note 95.Ibid

Note 96.Ibid

Note 97. WWF Statement on Recent Submissions Regarding Fisheries Subsidies to the WTO Negotiating Group on Rules (Geneva - 21 September 2007) TN/RL/GEN/134

Note 98.Schram-Stokke, O. (2001). Governing High Seas Fisheries: The Interplay of Global and Regional Regimes (ed.), 303.

Note 100.WWF website dedicated to IUU fishing, last viewed 09 May 2010. [Online] Available: http://iuufishing.org/

Note 102. de La Fayette, L. (2006). 'The Role of the United Nations in International Oceans Governance' , in D Freestone, D \& Barnes, R \& Ong, D. (2006). The Law of the Sea: Progress and Prospects, 63.

Note 103.Supra note 91 